\title{
MOTHER-TO-CHILD TRANSMISSION OF DIFFERENT HIV-1 SUBTYPES AMONG ARV NAÏVE INFECTED PREGNANT WOMEN IN NIGERIA
}

\author{
G.N. ODAIBO(1), D.O. OLALEYE(1), L. HEYNDRICKX(2), K. VEREECKEN(2), K. HOUWER(2) \& W. JASSENS(2)
}

\begin{abstract}
SUMMARY
The rate of mother-to-child transmission (MTCT) of HIV as well as the implications of the circulating multiple subtypes to MTCT in Nigeria are not known. This study was therefore undertaken to determine the differential rates of MTCT of HIV-1 subtypes detected among infected pregnant women before ARV intervention therapy became available in Nigeria.

Twenty of the HIV-positive women who signed the informed consent form during pregnancy brought their babies for followup testing at age 18-24 months. Plasma samples from both mother and baby were tested for HIV antibody at the Department of Virology, UCH, Ibadan, Nigeria. All positive samples (plasma and peripheral blood mononuclear cells - PBMCs) were shipped to the Institute of Tropical Medicine, Antwerp, Belgium, where the subtype of the infecting virus was determined using the HMA technique.
\end{abstract}

Overall, a mother-to-child HIV transmission rate of $45 \%$ was found in this cohort. Specifically, 36.4\%, $66.7 \%$ and $100 \%$ of the women infected with HIV-1 CRF02 (IbNg), G and B, respectively, transmitted the virus to their babies.

As far as it can be ascertained, this is the first report on the rate of MTCT of HIV in Nigeria. The findings reported in this paper will form a useful reference for assessment of currently available therapeutic intervention of MTCT in the country.

KEYWORDS: Mother-to-child transmission; HIV subtypes; Nigeria.

\section{INTRODUCTION}

UNAIDS estimates that over 42 million people are currently infected with the human immunodeficiency virus (HIV), 2.4 million of whom are children ${ }^{23}$. Out of the total HIV-infected children worldwide, $87 \%$ are in Africa ${ }^{22,23}$. It has been suggested that over $90 \%$ of the children living with HIV in sub-Saharan Africa may have acquired the infection through mother-to-child transmission ${ }^{23}$. According to UNAIDS, about 1600 infants are born with HIV infection daily worldwide $^{6}$. However, the rates of MTCT of HIV vary by geographical location. The efficiency of MTCT of HIV-1 prior to the PACTG 076 trial of Zidovudine prophylaxis in HIV-infected mothers ranged from $7 \%$ in Europe to $40 \%$ in Africa and $48 \%$ in India 6

The wide geographical differences in the prevalence and rate of MTCT of HIV-1 may be related to the circulating viral genotypes in different areas. Most of the countries reporting lower MTCT rates of HIV have predominantly subtype B while multiple non-B subtypes and recombinant forms (CRFs) circulate in Africa, probably with higher efficiency of $\mathrm{MTCT}^{12,19,25}$.

Several studies from Nigeria have shown circulation of multiple HIV-1 subtypes in most parts of the country. Clades identified in these studies include group M subtypes A, B, C, G, CRF02 ( IbNg) and group $\mathrm{O}$, with $\mathrm{CRF} 02$ ( $\mathrm{IbNg}$ ) and subtype $\mathrm{G}$ being the predominant strains circulating in the country ${ }^{10,13,16,18}$. In an earlier communication on HIV subtypes among discordant and concordant couples we reported that HIV-1 subtype C may be more efficiently transmitted heterosexually than the other subtypes detected in Nigeria ${ }^{14}$.

The rate of MTCT of HIV as well as the implications of cocirculation of multiple subtypes of the virus in the country has not been well documented. This study was therefore undertaken to determine the differential rates of MTCT of HIV-1 subtypes found among infected pregnant women before ARV therapeutic intervention became available in Nigeria. Our finding is hereby presented in view of the recently introduced prevention of mother to child transmission (PMTCT) intervention programmes in the country.

(1) Department of Virology, University College Hospital, Ibadan, Nigeria

(2) Institute of Tropical Medicine, Antwerp, Belgium.

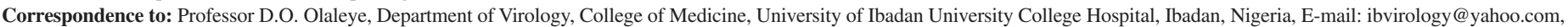
foreodaibo@hotmail.com 


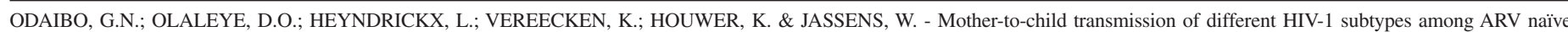
infected pregnant women in Nigeria. Rev. Inst. Med. trop. S. Paulo, 48(2):77-80, 2006.

\section{MATERIALS AND METHODS}

Study site and subject enrollment: This study was carried out among pregnant women referred, from some hospitals and maternities within the Ibadan metropolis of southwestern Nigeria, to the Department of Virology, UCH, Ibadan, for HIV testing, from 1996 to 1999. The women were counseled and their consent obtained for enrollment in the study. Only HIV-positive pregnant women who agreed to present their babies for testing at age 18-24 months and signed the informed consent form to participate were enrolled in the study. Out of the $50 \mathrm{HIV}$-positive women counseled, 35 gave consent to participate, and only 20 brought their babies for follow-up testing at age 18-24 months.

Sample collection, processing and storage: Ten millilitres of blood sample were collected, by venepuncture, into sterile tubes containing heparin or EDTA from each of the HIV-positive pregnant women while $5 \mathrm{~mL}$ of blood were collected from the children during the follow-up visit. The blood samples were centrifuged and plasma separated into two aliquots within four hours of sample collection and stored at $-20{ }^{\circ} \mathrm{C}$ until tested. In addition, peripheral blood mononuclear cells (PBMCs) were separated from the whole blood by the ficol hypaque technique and stored in $10 \%$ DMSO at $-20{ }^{\circ} \mathrm{C}$ until analyzed.

\section{Laboratory testing}

Serology: All the plasma samples were tested for the presence of HIV-1/2 antibodies with a commercial ELISA kit, Genscreen (Pasteur, Sanofi Diagnostics, Paris, France). ELISA reactive samples were further subjected to Western blotting analysis according to the manufacturer's instructions (Lav-Blot 1, Biorad, France).

RNA/DNA extraction and amplification of HIV gene: One aliquot of the stored plasma and PBMC were transported on ice to the Virology unit of the Institute of Tropical Medicine, Antwerp, Belgium. RNA extractions from plasma were performed using the Boom's method $^{1}$ while DNA was extracted from the PBMCs using a commercial kit (Qiagen/Westburg, Leusden, The Netherlands).

A segment of the gag and env gene were amplified using primers and cycling conditions as earlier described by HEYNDRICKX et al. ${ }^{7}$.

Subtyping: Subtyping of the amplified product was performed using the HMA technique for env as described by DELWART et al. ${ }^{5}$ and as modified for gag by HEYNDRICKX et al. ${ }^{7}$.

\section{RESULTS}

A total of 35 HIV-1 positive pregnant women were enrolled between 1996 and 1999 for the study. However, only 20 of them who brought their children for follow-up testing at age 18-24 months were included for the analysis. One of the mothers had a set of twins. The mean age of the mothers was 33 years (Range: 22-43 years). Plasma samples from nine of the 20 children tested at follow-up visit were confirmed HIV-1 positive by Western blot while 11 were seronegative, giving an overall transmission of rate $45 \%$. Samples from the twins of the infected mother were seronegative.

Of the 20 women, we were able to amplify the fragments of gag gene in 19 , env gene in 17 and from both regions in 16 of the samples. Overall, 11 (55\%) CRF02-AG (IbNg), three (15\%) subtype $\mathrm{G}$ and two (10\%) subtype B were identified as the infecting virus subtypes among the women. The table shows the pattern of MTCT of the subtypes identified in the study. Four (36.4\%), $2(6.7 \%)$ and two $(100 \%)$ of the women infected with HIV-1 CRF02-AG (IbNg), G and B respectively transmitted the virus to their children.

\section{DISCUSSION}

Undoubtedly, most cases of HIV infection in infants in both developed and developing countries have occurred as a result of transmission from infected mothers to their babies ${ }^{23}$. However, while MTCT of HIV has been substantially reduced through various preventive and therapeutic efforts in the developed countries, it remains an important route of transmission of the virus to children in most developing countries ${ }^{9,23}$. Hitherto, the rate of MTCT of HIV in Nigeria has not been determined, although there have been reports showing high number of paediatric infection with or without seropositive mothers ${ }^{15}$. Overall, $45 \%$ mother-child pair of HIV infection was found in this study. This finding is comparable with the rate of $40-50 \%$ reported from other parts of Africa when therapeutic intervention was not available 6 . The rate is however considerably higher than about 7$30 \%$ MTCT of HIV reported from North America and Western Europe before therapy became available to prevent infection of babies from their positive mothers ${ }^{6}$.

Although the exact factors that determine MTCT of HIV are not fully understood, certain maternal and viral factors have been associated with enhanced transmission of the virus from infected mothers to their babies $^{2,3,23}$. While some maternal factors like host genetics, CD4+ cell count, viral load, and rupture of membrane long before delivery have

Table 1

MTCT transmission of some HIV-1 subtypes in Nigeria

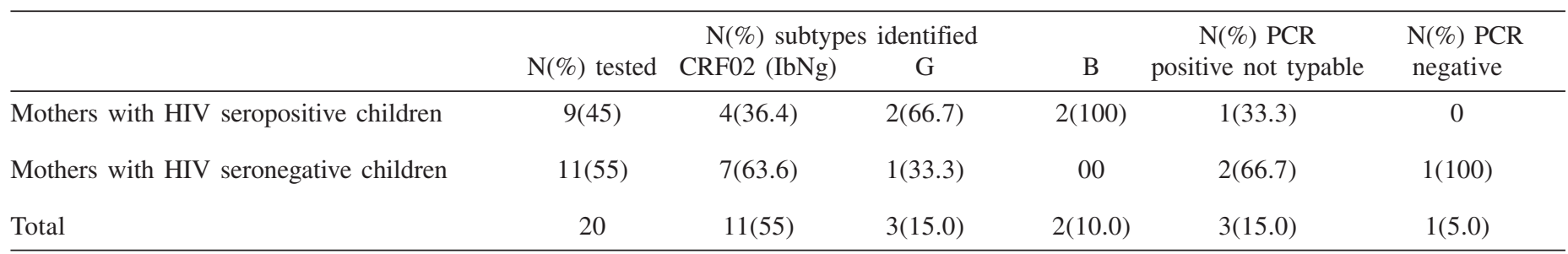




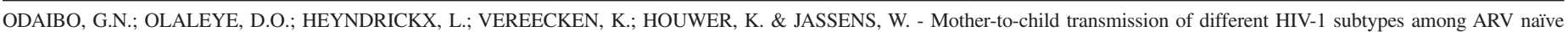
infected pregnant women in Nigeria. Rev. Inst. Med. trop. S. Paulo, 48(2):77-80, 2006.

been strongly associated with enhanced transmission ${ }^{17,20}$, little is known about the role of the infecting viral subtypes. Out of the 20 mothers whose babies were tested in this study, $11(55 \%)$ were infected with CRF02 (IbNg), an A/G recombinant that is the most predominant HIV1 subtype in West Africa ${ }^{4,11,16,18}$.

Further analysis of the results showed that four (36.4\%) of the 11 mothers infected with HIV-1 CRF02-AG (IbNg) transmitted the virus to their babies (Table 1). While the number of mothers infected with the other subtypes found in the study may be relatively small to make a conclusion, it is worthy of note that two $(66.7 \%)$ of the three mothers infected with HIV-1 subtype G transmitted the virus to their babies. On the other hand, only one $(33.3 \%)$ of the three mothers infected with other strains that could not be readily typed by the HMA method transmitted the virus to their babies. This observation on subtype $G$ is also interesting being another strain of HIV commonly found in Nigeria $^{16}$. While some investigators have argued that the subtype of HIV may not be related to efficiency of transmission of the virus ${ }^{6,12}$, others believe that it may be associated with the transmission of the virus from infected mother to child ${ }^{12}$.

Reports from Thailand suggest that heterosexual transmission may be more efficient with subtype E than subtype B virus ${ }^{21}$. Similarly, follow-up studies have shown that individuals infected with HIV-1 subtype D had faster disease progression than those infected with subtype A in Uganda ${ }^{8}$. In a recent study in Kenya, YANG et al. ${ }^{25}$ showed that the rates of MTCT were higher among women infected with subtype D (29.9\%) compared with those infected with subtype A (18.0\%) while recombinant strains were associated with higher rates than $\mathrm{A}$ and $\mathrm{D}$.

While there is need for further studies with larger sample sizes to establish the relevance of subtypes/CRFs in the MTCT of HIV in Nigeria, the findings reported in this paper will be a useful reference for the assessment of therapeutic intervention of MTCT of the virus recently introduced in the country.

\section{RESUMO}

\section{Transmissão materno-fetal de diferentes subtipos de HIV-1 entre gestantes infectadas na Nigéria}

A taxa de transmissão materno-fetal (MTCT) do HIV bem como as implicações dos múltiplos subtipos circulantes para MTCT na Nigéria não são conhecidos. Este estudo foi realizado para determinar as diferentes taxas de MTCT dos subtipos de HIV-1 detectados entre gestantes infectadas antes que a administração da terapia ARV estivesse disponível na Nigéria.

Vinte das mulheres HIV positivas que assinaram o consentimento durante a gravidez trouxeram seus filhos para seguimento na idade de 18-24 meses. Amostras de plasma de ambos, mãe e filho foram testadas para anticorpos HIV no Departamento de Virologia, UCH, Ibadan, Nigéria. Todas as amostras positivas (plasma e células mononucleares do sangue periférico - PBMCs) foram enviadas para o Instituto de Medicina Tropical da Antuérpia, Bélgica, onde os subtipos de vírus infectantes foram determinados utilizando-se a técnica HMA.

No conjunto, uma taxa de transmissão de HIV, materno-fetal, de $45 \%$ foi encontrada neste grupo. Especificamente, 36,4\%, 66,7\% e
100\% das mulheres infectadas com HIV-1 CRF02 (IbNg), G e B, respectivamente, transmitiram o vírus para seus filhos.

Até onde pode ser verificado, este é o primeiro relato da taxa de MTCT do HIV na Nigéria. Os achados relatados neste trabalho serão uma útil referência para estimar a qualidade das terapêuticas atuais disponíveis para MTCT neste país.

\section{ACKNOWLEDGEMENTS}

The authors acknowledge the support of both the staff of Department of Virology, UCH, Ibadan, Nigeria and the Virology unit of Institute of Tropical Medicine, Antwerp, Belgium. Funds for sample collection and initial HIV testing for mothers and babies was provided by University of Ibadan Senate research grant. The Elizabeth Glazer Pediatric AIDS Foundation (EGPAF), USA, kindly provided the travel and living expenses in Belgium and part of the reagent cost with a short-term travel grant to GNO.

\section{REFERENCES}

1. BOOM, R.; SOL, C.J.A.; SALIMANS, M.M.M. et al. - Rapid simple method for purification of nucleic acids. J. clin. Microbiol., 28: 495-503, 1990.

2. BULTERYS, M.; CHAO, A.; DUSHIMIMANA, A. et al. - Multiple sexual partners and mother to child transmission to HIV-1. AIDS, 7: 1639-1645, 1993.

3. BURNS, D.N.; LANDESMAN, S.; WRIGHT, D.J. et al. - Influence of other maternal variables on the relationship between maternal virus load and mother-to-infant transmission of human immunodeficiency virus type 1. J. infect. Dis., 175: 12061210,1997

4. CARR, J.K.; LAUKKANEN, T.; SALMINEN, M.O. et al. - Characterization of subtype A HIV-1 from Africa by full genome sequencing. AIDS, 13: 1819-1826, 1999.

5. DELWART, E.L.; SHPAER, E.G.; LOUWAGIE, J. et al. - Genetic relationships determined by a DNA heteroduplex mobility assay: analysis of HIV-1 env genes. Science, 262: 1257-1261, 1993.

6. GANGAKHEDKAR, R.R. - Chemoprophylaxis to reduce mother-to-child transmission of HIV-1 infection. In: NATIONAL CONFERENCE, 1., Delhi, November, 2001.

7. HEYNDRICKX, L.; JANSSENS, W.; ZEKENG, L. et al. - Simplified strategy for detection of recombinant human immunodeficiency virus type 1 group $\mathrm{M}$ isolates by gag/env heteroduplex mobility assay. Study Group on Heterogeneity of HIV Epidemics in African cities. J. Virol., 74: 363-370, 2000.

8. KALEEBU, P.; ROSS, A.; MORGAN, D. et al. - Relationship between HIV-1 env subtypes A and D and disease progression in a rural Uganda cohort. AIDS, 15: 293-299, 2001.

9. LUO, C. \& OULTER, B. - Diagnosis of pediatric HIV infection. In: ESSEX, M.; MBOUPS KANKI, P.; MARLINK, R.G. \& TLOU, S. AIDS in Africa. 2. ed. Kluwer Academic; Plenum Publishers, 2002. p. 458-468.

10. McCUTCHAN, F.E.; CARR, J.K.; BAJANI, M. et al. - Subtype G and multiple forms of $\mathrm{A} / \mathrm{G}$ intersubtype recombinant human immunodeficiency virus type 1 in Nigeria. Virology, 254: 226-234, 1999.

11. MONTAVON, C.; TOURE-KANE, C.; LIEGEOIS, F. et al. - Most env and gag subtype A HIV-1 viruses circulating in West and West Central Africa are similar to the prototype AG recombinant virus IBNG. J. Acquir. Immune Defic. Syndr., 23: 363$374,2000$.

12. MURRAY, M.; EMBREE, J.; RAMDAHIN, S. et al. - Effect of human immunodeficiency virus type 1 viral genotype on mother-to-child transmission of HIV-1. J. infect. Dis., 181: 746-749, 2000. 


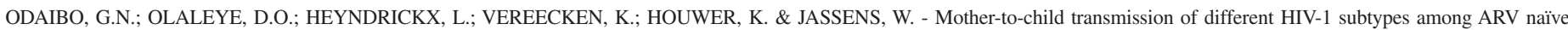
infected pregnant women in Nigeria. Rev. Inst. Med. trop. S. Paulo, 48(2):77-80, 2006.

13. ODAIBO, G.N.; OLALEYE, O.D.; RUPPACH, H. et al. - Multiple presence and heterogeneous distribution of HIV-1 subtypes in Nigeria. Biosci. Res. Commun., 13: 447-458, 2001

14. ODAIBO, G.N.; OLALEYE, D.O.; RUPPACH, H. et al. - Prevalence of HIV-1 subtypes in infected concordant and discordant couples in Nigeria. Biosci. Res. Commun., 13: $459-464,2001$.

15. ODAIBO, G.N.; BAMGBOSE, G.; JEGEDE, A.S. et al. - Demographic and laboratory evidence of non sexual transmission of HIV in Nigeria. Medimond S.r.l. Published. In: PROCEEDINGS OF THE XV INTERNATIONAL AIDS CONFERENCE, Thailand, 2004. E710L7663. p. 25-30.

16. OlALEYE, O.D.; SHENG, Z.; HOWARD, T. \& RASHEED, S. - Biological characterization of a new subtype A variant of human immunodeficiency virus type 1 from Nigeria. Biokemistr., 5: 51-60, 1995.

17. O'SHEA, S.; NEWELL, M.L.; DUNN, D.T. et al. - Maternal viral load, CD4 cell count and vertical transmission of HIV-1. J. med. Virol., 54: 113-117, 1998.

18. PEETERS, M.; ESU-WILliAMS, E.; VERGNE, L. et al. - Predominance of subtype A and G HIV type 1 in Nigeria, with geographical differences in their distribution. AIDS Res. hum. Retrovir., 16: 315-325, 2000.

19. RENJIFO, B.; FAWZI, W.; MWAKAGILE, D. et al. - Differences in perinatal transmission among HIV-1 genotypes. J. hum. Virol., 4: 16-25, 2001.
20. St. LOUIS, M.E.; KAMENGA, M.; BROWN, C. et al. - Risk of perinatal HIV-1 transmission according to maternal immunologic, virologic and placental factors. $\mathbf{J}$. Amer. Med. Ass., 269: 2853-2859, 1993.

21. SUBBARAO, S.; LIMPAKARNJANARAT, K.; MASTRO, T.D. et al. - HIV type 1 in Thailand, 1994-1995: persistence of two subtypes with low genetic diversity. AIDS Res. Hum. Retroviruses, 14: 319-327, 1998.

22. UNAIDS/WHO - AIDS epidemic update. UNAIDS 44E-WHO/CDS/CSR/EDC/2000.9 Geneva, UNAIDS, December 2000.

23. UNAIDS - Report on the global AIDS epidemic. Geneva, December 2004.

24. WILBOUGHBY, A. - Mother-to-child transmission of HIV. In: ESSEX, M.; MBOUPS KANKI, P.; MARLINK, R.G. \& TLOU, S. ed. AIDS in Africa. 2. ed. Kluwer Academic; Plenum Publishers, 2002. p. 251-263.

25. YANG, C.; LI, M.; NEWMAN, R.D. et al. - Genetic diversity of HIV-1 in western Kenya subtype-specific differences in mother-to-child transmission. AIDS, 17: 1667-1674, 2003

Received: 25 July 2005

Accepted: 1 November 2005 